Article

\title{
Synthesis and Characterization of the $\mathrm{CaTiO}_{3}: \mathrm{Eu}^{3+}$ Red Phosphor by an Optimized Microwave-Assisted Sintering Process
}

\author{
Haifeng Wang ${ }^{1,2, *}$, Jianwei Lu ${ }^{1,2}$, Ruoxuan Wang ${ }^{1,2}$, Yungu Dong ${ }^{1,2}$ and Linfeng Ding ${ }^{1,2, *}$ \\ 1 College of Materials Science and Engineering, Donghua University, Shanghai 201620, China; \\ 2190454@dhu.edu.cn (J.L.); 2170384@dhu.edu.cn (R.W.); 2180454@dhu.edu.cn (Y.D.) \\ 2 Engineering Research Center of Advanced Glass Manufacturing Technology, Ministry of Education, \\ Donghua University, Shanghai 201620, China \\ * Correspondence: whf2008@dhu.edu.cn (H.W.); linfeng.ding@dhu.edu.cn (L.D.)
}

Received: 22 January 2020; Accepted: 12 February 2020; Published: 15 February 2020

\begin{abstract}
The synthesis process has a significant influence on the properties of $\mathrm{Ca}_{1-\mathrm{x}} \mathrm{TiO}_{3}: \mathrm{Eu}^{3+} \mathrm{x}$ phosphors; thus, an optimized process will lead to a better performance of the $\mathrm{Ca}_{1-\mathrm{x}} \mathrm{TiO}_{3}: \mathrm{Eu}^{3+} \mathrm{x}$ phosphors. In this work, the feasibility of synthesizing the $\mathrm{Ca}_{1-\mathrm{x}} \mathrm{TiO}_{3}: \mathrm{Eu}^{3+}{ }_{x}$ phosphor with a good luminescent performance by combining the chemical co-precipitation method and microwave-assisted sintering was studied. The precursor of $\mathrm{Ca}_{1-\mathrm{x}} \mathrm{TiO}_{3}: \mathrm{Eu}^{3+}{ }_{x}$ phosphors were prepared by the chemical co-precipitation method. To find an optimized process, we applied both of the traditional (furnace) sintering and the microwave-assisted sintering to synthesize the $\mathrm{Ca}_{1-\mathrm{x}} \mathrm{TiO}_{3}: \mathrm{Eu}^{3+}{ }_{\mathrm{x}}$ phosphors. We found out that a sintering power of $528 \mathrm{~W}$ for $50 \mathrm{~min}$ (temperature around $950{ }^{\circ} \mathrm{C}$ ) by a microwave oven resulted in similar emission intensity results compared to traditional furnace sintering at $900{ }^{\circ} \mathrm{C}$ for $2.5 \mathrm{~h}$. The synthesized $\mathrm{Ca}_{1-\mathrm{x}} \mathrm{TiO}_{3}: \mathrm{Eu}^{3+}{ }_{\mathrm{x}}$ phosphors has an emission peak at $617 \mathrm{~nm}\left({ }^{5} \mathrm{D}_{0} \rightarrow{ }^{7} \mathrm{~F}_{2}\right)$, which corresponds to the red light band. This new synthesized method is an energy efficient, time saving, and environmentally friendly means for the preparation of $\mathrm{Ca}_{1-\mathrm{x}} \mathrm{TiO}_{3}: \mathrm{Eu}^{3+}{ }_{\mathrm{x}}$ red phosphor with good luminescent performance.
\end{abstract}

Keywords: $\mathrm{CaTiO}_{3}: \mathrm{Eu}^{3+}$ red phosphors; microwave-assisted sintering; chemical co-precipitation method; luminescent properties

\section{Introduction}

Calcium titanate $\left(\mathrm{CaTiO}_{3}\right)$ represents one of the most important classes of mixed oxides owing to its good chemical and thermal stability as well as great mechanical resistance. Particularly, rare earth-activated $\mathrm{CaTiO}_{3}$ phosphors [1-4] exhibit high-efficiency luminescent properties and, therefore, are promising for using in various optoelectronic devices, e.g., field-emission displays and long persistent phosphorescent phosphors. Such phosphors are crucial for applications in white light-emitting diodes to adjust their chromogenic performance, color and temperature [5].

$\mathrm{Eu}^{3+}$ ions have significant importance due to their potential application as red phosphors, electroluminescent devices, optical amplifiers, and lasers when it is used as doping in a great variety of materials [6]. To date, the perovskite phosphors can be prepared by various methods [1-8], including high-temperature solid-phase sintering, the sol-gel method, the chemical coprecipitation method, a hydrothermal process, the combustion method, etc. Studies [1-8] have shown that the preparation process has a significant influence on the properties of $\mathrm{Ca}_{1-\mathrm{x}} \mathrm{TiO}_{3}: \mathrm{Eu}^{3+} \times$ phosphors; thus, an optimized process will lead to a better performance of the $\mathrm{Ca}_{1-\mathrm{x}} \mathrm{TiO}_{3}: \mathrm{Eu}^{3+}{ }_{\mathrm{x}}$ phosphors.

The chemical co-precipitation method $[9,10]$ to prepare $\mathrm{Ca}_{1-\mathrm{x}} \mathrm{TiO}_{3}: \mathrm{Eu}^{3+} \times$ phosphors is processed by dissolving the calcium carbonate $\left(\mathrm{CaCO}_{3}\right)$ in the acetic acid and then mixing the solution with 
the europium acetate and the titanium dioxide by stirring for the precipitation. The precipitation is washed several times, which is followed by a traditional sintering (in a muffle furnace) to obtain the $\mathrm{Ca}_{1-\mathrm{x}} \mathrm{TiO}_{3}: \mathrm{Eu}^{3+}$ x phosphors powder.

In recent years, the microwave-assisted sintering method [2,11-14] has been widely applied in the synthesis of phosphor and ceramic materials due to its advantages of rapid heating rate and energy efficiency [15]. Different from the conventional sintering method, with radiation or conduction from the surface to the core as the main heat transfer mechanism, the microwave-assisted sintering procedure heats the whole sample by volumetric heating from microwaves [12]. Thus, to combine advantages from the chemical co-precipitation method and the microwave-assisted sintering method will be an optimized process (e.g., time and energy saving) to prepare $\mathrm{Ca}_{1-\mathrm{x}} \mathrm{TiO}_{3}: \mathrm{Eu}^{3+}{ }_{\mathrm{x}}$ phosphors with better performance.

In this work, the precursor of $\mathrm{Ca}_{1-\mathrm{x}} \mathrm{TiO}_{3}: \mathrm{Eu}^{3+}{ }_{\mathrm{x}}$ phosphor was synthesized by the chemical co-precipitation method. Then, we applied both the traditional sintering and the microwave-assisted sintering to prepare the $\mathrm{Ca}_{1-\mathrm{x}} \mathrm{TiO}_{3}: \mathrm{Eu}^{3+}{ }_{\mathrm{x}}$ phosphor. The luminescence properties from the optimized process were studied and compared to the traditional method.

\section{Experimental Procedures}

\subsection{Sample Preparation}

Main raw materials including $\mathrm{Ca}\left(\mathrm{NO}_{3}\right)_{2} \cdot 4 \mathrm{H}_{2} \mathrm{O}, \mathrm{Eu}\left(\mathrm{NO}_{3}\right)_{3} \cdot 6 \mathrm{H}_{2} \mathrm{O}, \mathrm{C}_{2} \mathrm{H}_{2} \mathrm{O}_{4} \cdot 2 \mathrm{H}_{2} \mathrm{O},\left(\mathrm{NH}_{4}\right)_{2} \mathrm{C}_{2} \mathrm{O}_{4}$, and $\mathrm{C}_{16} \mathrm{H}_{36} \mathrm{O}_{4}$ Ti with a purity of $99.9 \%$ (Sinopharm Group, Shanghai, China) were used as starting materials.

The sample synthesizing process is presented in Figure 1. Firstly, we applied the chemical co-precipitation method to synthesize the precursor. The $\mathrm{C}_{2} \mathrm{H}_{2} \mathrm{O}_{4} \cdot 2 \mathrm{H}_{2} \mathrm{O}$ and $\mathrm{C}_{16} \mathrm{H}_{36} \mathrm{O}_{4} \mathrm{Ti}$ were dissolved in the ethanol to get solutions $\mathrm{A}$ and $\mathrm{B}$. The $\left(\mathrm{NH}_{4}\right)_{2} \mathrm{C}_{2} \mathrm{O}_{4}$ was dissolved in the distilled water to obtain a solution $\mathrm{C}$. The $\mathrm{Ca}\left(\mathrm{NO}_{3}\right)_{2} \cdot 4 \mathrm{H}_{2} \mathrm{O}$ and $\mathrm{Eu}\left(\mathrm{NO}_{3}\right)_{3} \cdot 6 \mathrm{H}_{2} \mathrm{O}$ were dissolved in the distilled water to get solution $\mathrm{D}$. Solution $\mathrm{A}$ and solution $\mathrm{C}$ were dropwise added to solution $\mathrm{B}$ and magnetic stirred to obtain a clear solution $\mathrm{E}$, followed by dropwise adding solution $\mathrm{D}$ to solution $\mathrm{E}$ and magnetic stirring for $2 \mathrm{~h}$. The precipitation was centrifuged washing and dried to get the precursor. Then, the precursors were transferred into alumina crucibles and heated in a muffle furnace at $600-900{ }^{\circ} \mathrm{C}$ for $2.5 \mathrm{~h}$ in air as well as heated in a microwave oven (Galanz, G80F 2.45G Hz) at 528-800 W for 10-60 min to prepare the $\mathrm{Ca}_{1-\mathrm{x}} \mathrm{TiO}_{3}: \mathrm{Eu}^{3+}{ }_{\mathrm{x}}$ phosphors. During the microwave assisted sintering, a small crucible with dry $\mathrm{Ca}_{0.97} \mathrm{TiO}_{3}: \mathrm{Eu}^{3+}{ }_{0.03}$ phosphor powder was placed in a large crucible filled with $3 / 4$ volume of activated carbon. The precursor was heated by heat transfer from the activated carbon to prepare the $\mathrm{Ca}_{0.97} \mathrm{TiO}_{3}$ : $\mathrm{Eu}^{3+} 0.03$ phosphor.

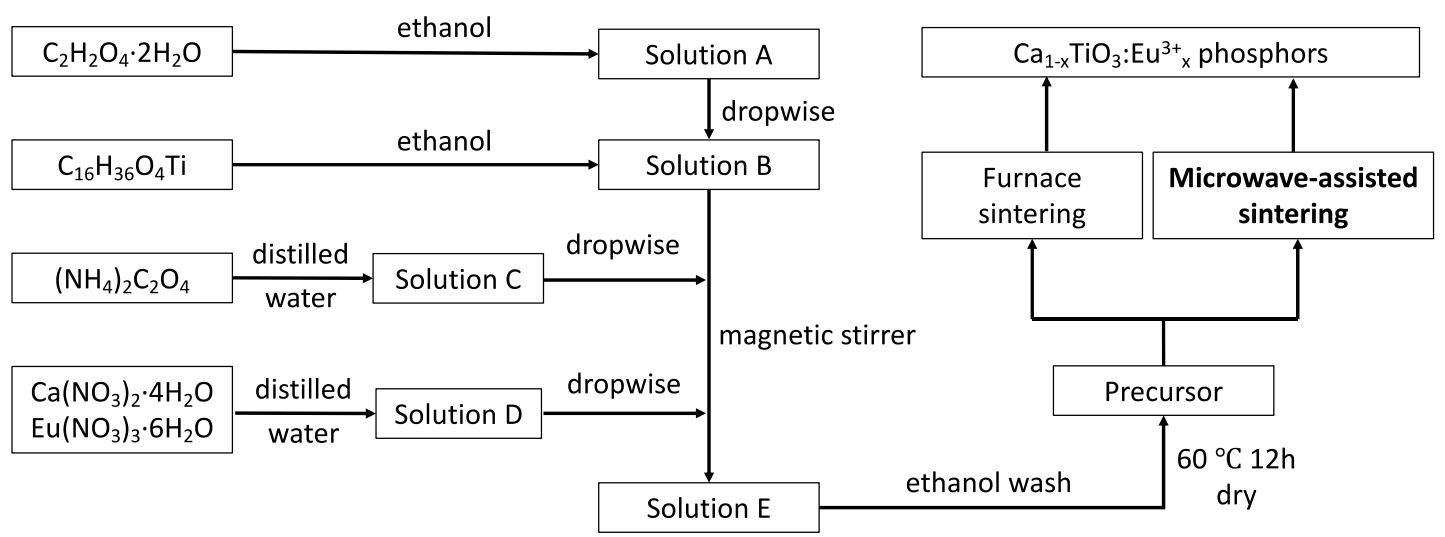

Figure 1. Flow chart of the experimental process for synthesizing the $\mathrm{Ca}_{1-\mathrm{x}} \mathrm{TiO}_{3}: \mathrm{Eu}^{3+}{ }_{\mathrm{x}}$ phosphors. 


\subsection{Characterization Techniques}

The chemical structure of the precursor was measured by applying Fourier transform infrared spectroscopy (FT-IR, Nexus-670, Waltham, MA, USA) measurements, where the precursor samples were mounted in the $\mathrm{KBr}$ pelletized disks and measured in the $400-3600 \mathrm{~cm}^{-1}$ region with a resolution of $2 \mathrm{~cm}^{-1}$. The thermal properties of the precursor were tested using a simultaneous thermal analysis (TG-DSC, STA409PC, Selb, Germany) in air atmosphere. The crystal information was analyzed by an X-ray diffractometer (XRD, D/max-2500PC, Rigaku, Japan) in air atmosphere. The micromorphology of the samples was studied by using field emission scanning electron microscope (SEM, S-3000N, Tokyo, Japan). The luminescent properties of the phosphors were tested by the fluorescence spectroscopy (FP-6600, Tokyo, Japan).

\section{Results and Discussion}

\subsection{Precursor Analysis}

In order to understand the structure of precursor (from the chemical co-precipitation method $[9,10]$ ) and carry out subsequent processing, the precursor was tested by FT-IR, and the results are shown in the Figure 2. From the FT-IR curve, the peak at around $3434 \mathrm{~cm}^{-1}$ is the anti-symmetry and telescopic symmetrical vibration of $\mathrm{OH}$, which corresponds to the $\mathrm{H}-\mathrm{O}-\mathrm{H}$ group of water bound in the precursor. The peak around $1600 \mathrm{~cm}^{-1}$ is the vibration of $\mathrm{C}=\mathrm{O}$, which corresponds to the carbon-oxygen double bond inside the $\mathrm{MTiO}\left(\mathrm{C}_{2} \mathrm{O}_{4}\right) \cdot 4 \mathrm{H}_{2} \mathrm{O}$. The metal cations and complexes of $\mathrm{TiO}\left(\mathrm{C}_{2} \mathrm{O}_{4}\right)^{2-}$ are uniformly represented by $\mathrm{MTiO}\left(\mathrm{C}_{2} \mathrm{O}_{4}\right)[16]$.

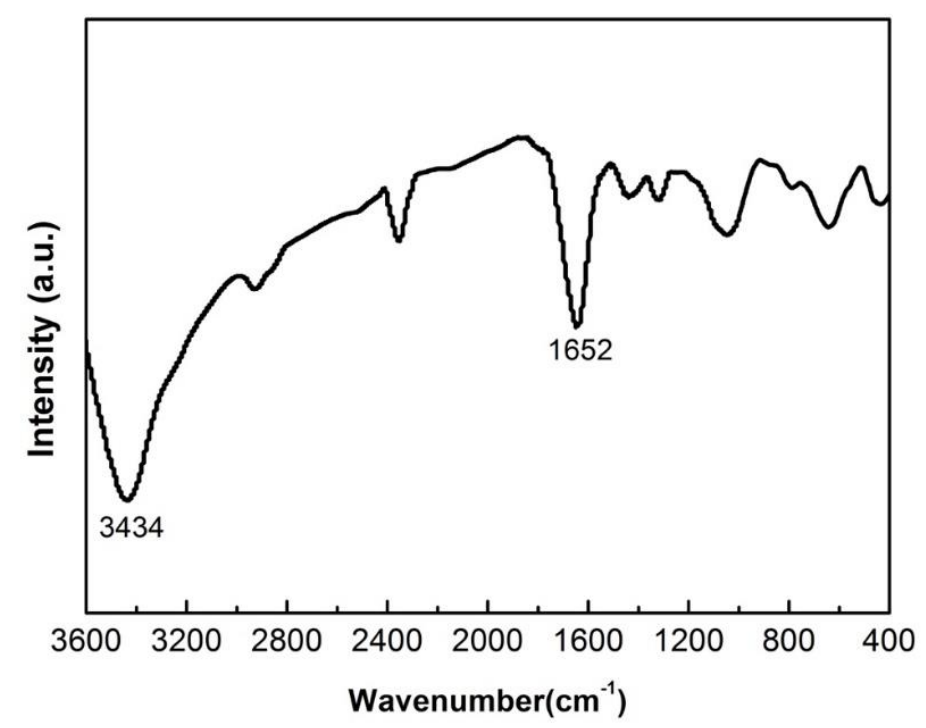

Figure 2. The FT-IR plot of the precursor from the chemical co-precipitation method.

To optimize the sintering process, the understanding of the thermal properties of the precursor is crucial. Figure 3 shows the thermal decomposition of the precursor. The TG curve has a clear three-stage decline during the heating process which is corresponding to the three endothermic peaks in the DSC curve [17-19]. At the temperature before $200^{\circ} \mathrm{C}$ (stage one), the precursor first lost the free water and then lost the bound water. The endothermic peak around $200^{\circ} \mathrm{C}$ in the DSC curve indicates the loss of bound water. The reaction [17] can be represented by Equation (1).

$$
\mathrm{MTiO}\left(\mathrm{C}_{2} \mathrm{O}_{4}\right) \cdot 4 \mathrm{H}_{2} \mathrm{O} \rightarrow \mathrm{MTiO}\left(\mathrm{C}_{2} \mathrm{O}_{4}\right)_{2}+4 \mathrm{H}_{2} \mathrm{O}
$$


The second stage at the temperature range of $275-457^{\circ} \mathrm{C}$, where the precursor decomposed to $\mathrm{MCO}_{3}$ and $\mathrm{TiO}_{2}$ by releasing the $\mathrm{CO}$ and $\mathrm{CO}_{2}$. The process companies by an obvious weight loss [17] which can be represented by Equation (2).

$$
\mathrm{MTiO}\left(\mathrm{C}_{2} \mathrm{O}_{4}\right)_{2} \rightarrow \mathrm{MCO}_{3}+\mathrm{TiO}_{2}+\mathrm{CO}+\mathrm{CO}_{2}
$$

The third stage mainly occurred in solid-phase reaction at $500-900{ }^{\circ} \mathrm{C}$. The reaction process [17] is shown in Equation (3).

$$
\mathrm{MCO}_{3}+\mathrm{TiO}_{2} \rightarrow \mathrm{MTiO}_{3}+\mathrm{CO}_{2}
$$

The TG curve is getting flat when the temperature is higher than $715^{\circ} \mathrm{C}$, which indicates that the reaction was completed.

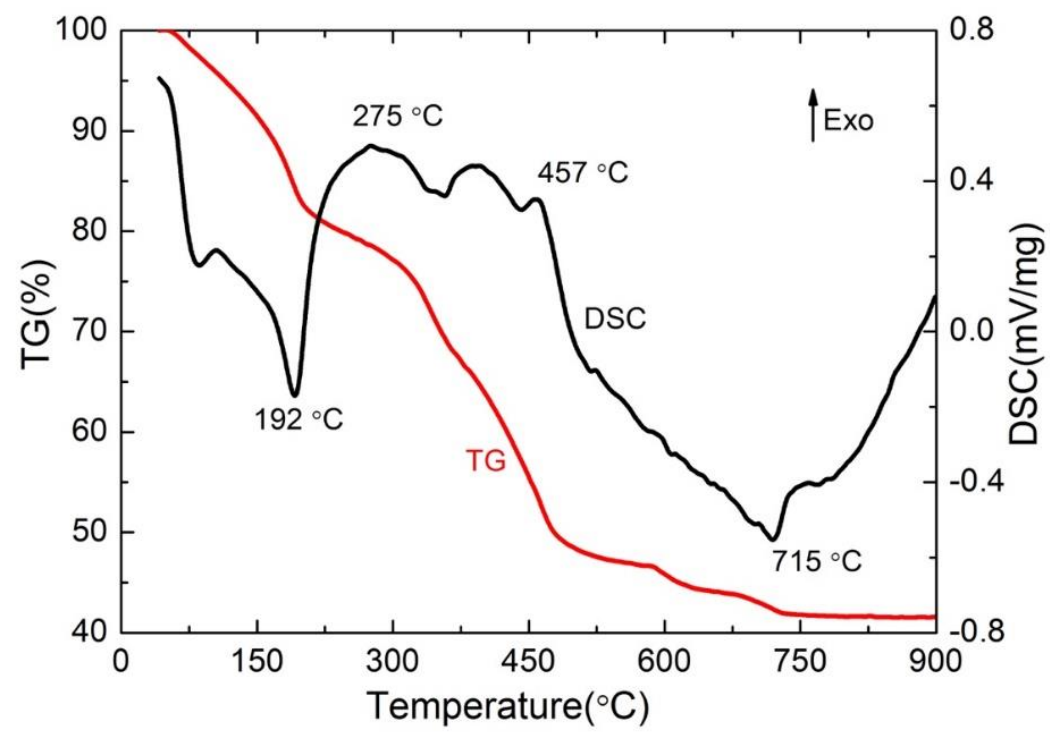

Figure 3. The TG-DSC curve of the precursor.

\section{2. $\mathrm{Ca}_{1-x} \mathrm{TiO}_{3}: \mathrm{Eu}^{3+}{ }_{x}$ Phosphor Synthesized by the Traditional Sintering Processes}

Based on the TG-DSC curve (Figure 3), the $\mathrm{MTiO}_{3}$ will be generated at a temperature higher than $600{ }^{\circ} \mathrm{C}$. Thus, the effect of sintering temperature on crystal formation and luminescence properties are firstly explored.

Figure 4 shows the XRD patterns of the $\mathrm{Ca}_{1-x} \mathrm{TiO}_{3}: \mathrm{Eu}^{3+}$ x phosphor samples at different sintering temperatures and the same isothermal holding for $2.5 \mathrm{~h}$. It can be seen from Figure 4 that the $\mathrm{Ca}_{1-\mathrm{x}} \mathrm{TiO}_{3}: \mathrm{Eu}^{3+}{ }_{x}$ has been synthesized at $600{ }^{\circ} \mathrm{C}$ while contains a certain amount of $\mathrm{TiO}_{2}[20,21]$. When the sintering temperature is higher than $650{ }^{\circ} \mathrm{C}$, the pure $\mathrm{Ca}_{1-\mathrm{x}} \mathrm{TiO}_{3}: \mathrm{Eu}^{3+}$ x phosphor can be produced (without $\mathrm{TiO}_{2}$ crystal peak). The diffraction peak (diffraction angle: $33.24^{\circ}, 47.74^{\circ}, 59.54^{\circ}$ ) corresponds to the standard card JCPDS NO.42-0423, which is the orthorhombic $\mathrm{CaTiO}_{3}$ structure. Moreover, the intensity of the standard diffraction peak is getting stronger with increasing the sintering temperature. The intensity of the standard diffraction peak is greatly enhanced at sintering temperature higher than $800{ }^{\circ} \mathrm{C}$, which indicates good crystallization.

Figure 5 shows the emission spectra under an excitation wavelength of $398 \mathrm{~nm} \mathrm{of}$ $\mathrm{Ca}_{0.97} \mathrm{TiO}_{3}: \mathrm{Eu}^{3+}{ }_{0.03}$ prepared at different traditional sintering temperature. It can be seen from Figure 5 that the luminous performance of the $\mathrm{Ca}_{0.97} \mathrm{TiO}_{3}: \mathrm{Eu}^{3+}{ }_{0.03}$ powder is continuously increasing with increasing of sintering temperature. The overall trend of luminescent properties is consistent with the trend of the crystal structure presented by XRD. In other words, the crystallization is not complete at relatively lower temperatures under $800{ }^{\circ} \mathrm{C}$. The incomplete crystallization will result in weak light intensity. 


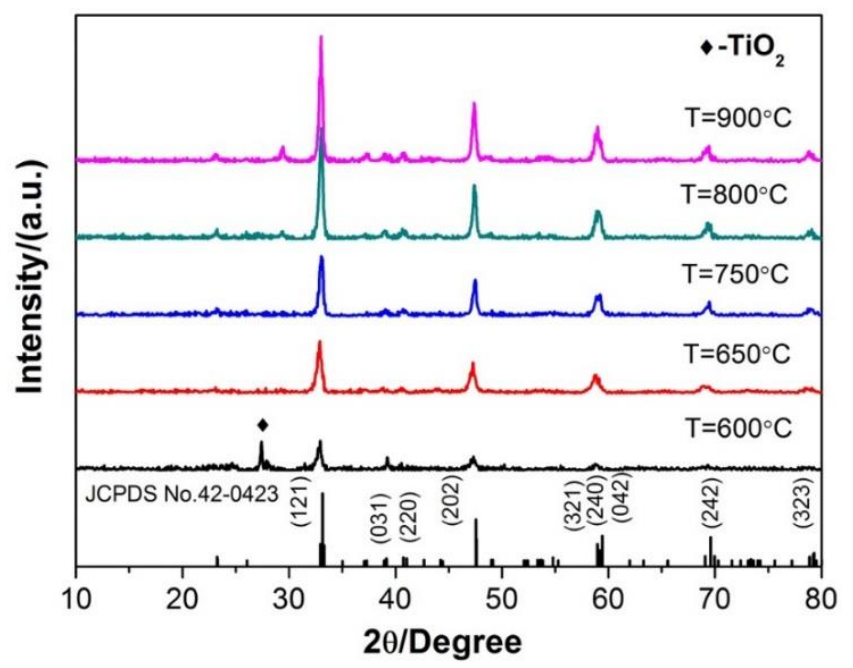

Figure 4. XRD patterns of the $\mathrm{Ca}_{1-\mathrm{x}} \mathrm{TiO}_{3}: \mathrm{Eu}^{3+} \times$ phosphor samples at different traditional sintering temperatures and same isothermal holding for $2.5 \mathrm{~h}$.

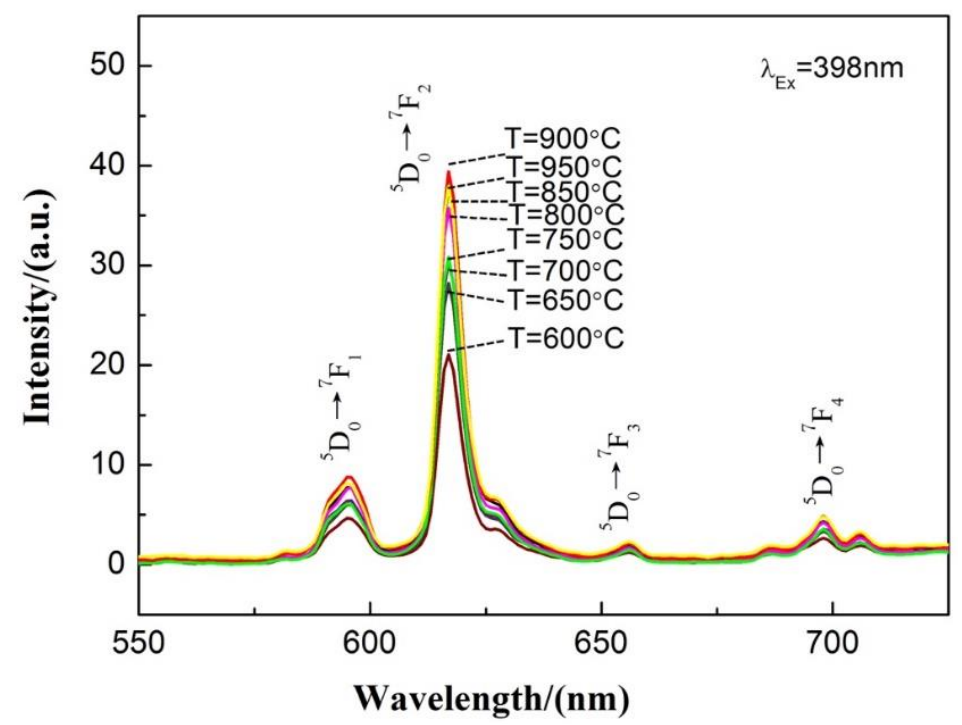

Figure 5. Emission spectra under an excitation wavelength of $398 \mathrm{~nm}$ of the $\mathrm{Ca}_{0.97} \mathrm{TiO}_{3}: \mathrm{Eu}^{3+}{ }_{0.03}$ prepared at different traditional sintering temperature.

Based on the results from the $\mathrm{XRD}$ and the luminescence properties, a traditional sintering temperature of $900{ }^{\circ} \mathrm{C}$ is the best process for preparing the $\mathrm{Ca}_{0.97} \mathrm{TiO}_{3}: \mathrm{Eu}^{3+}{ }_{0.03}$ phosphor.

To determine the best concentration of $\mathrm{Eu}^{3+}$ in the $\mathrm{Ca}_{1-\mathrm{x}} \mathrm{TiO}_{3}: \mathrm{Eu}^{3+}{ }_{x}$ phosphor, the $\mathrm{Ca}_{1-\mathrm{x}} \mathrm{TiO}_{3}: \mathrm{Eu}^{3+}{ }_{x}$ phosphors doped with various concentrations of $\mathrm{Eu}^{3+}$ are synthesized. The XRD patterns of the $\mathrm{Ca}_{1-\mathrm{x}} \mathrm{TiO}_{3}: \mathrm{Eu}^{3+}$ x phosphors doped with various concentrations of $\mathrm{Eu}^{3+}$ are shown in Figure 6. The main diffraction peak (diffraction angle: $33.24^{\circ}, 47.74^{\circ}, 59.54^{\circ}$ ) is consistent with the standard card JCPDS NO.42-0423, which is the orthorhombic $\mathrm{CaTiO}_{3}$ structure. The $\mathrm{TiO}_{2}$ peaks are also detected in the XRD pattern, which is due to the increase of $\mathrm{Eu}^{3+}$ accompanied by an excessive adding of $\mathrm{Ti}$ to ensure the complete chemical reaction of the metal cation $\left(\mathrm{Ca}^{2+}, \mathrm{Eu}^{3+}\right)$ and $\left[\mathrm{TiO}\left(\mathrm{C}_{2} \mathrm{O}_{4}\right)_{2}\right]^{2-}$. Table 1 shows the lattice constant of the $\mathrm{Ca}_{1-\mathrm{x}} \mathrm{TiO}_{3}: \mathrm{Eu}^{3+}$ x phosphors calculated by JADE software (6.5). It can be seen in Table 1 that the lattice constant decreases slightly with the addition of $\mathrm{Eu}^{3+}$ content, which is as a reason for the distance decrease of the lattice and the surrounding $\mathrm{O}^{2-}$ ion. Indeed, the ion radius $(94.7 \mathrm{pm})$ of $\mathrm{Eu}^{3+}$ is slightly smaller than the ion radius $(100 \mathrm{pm})$ of $\mathrm{Ca}^{2+}$. Moreover, the change of lattice constant also proved that the $\mathrm{Eu}^{3+}$ ions are successfully doped into the crystal structure. 


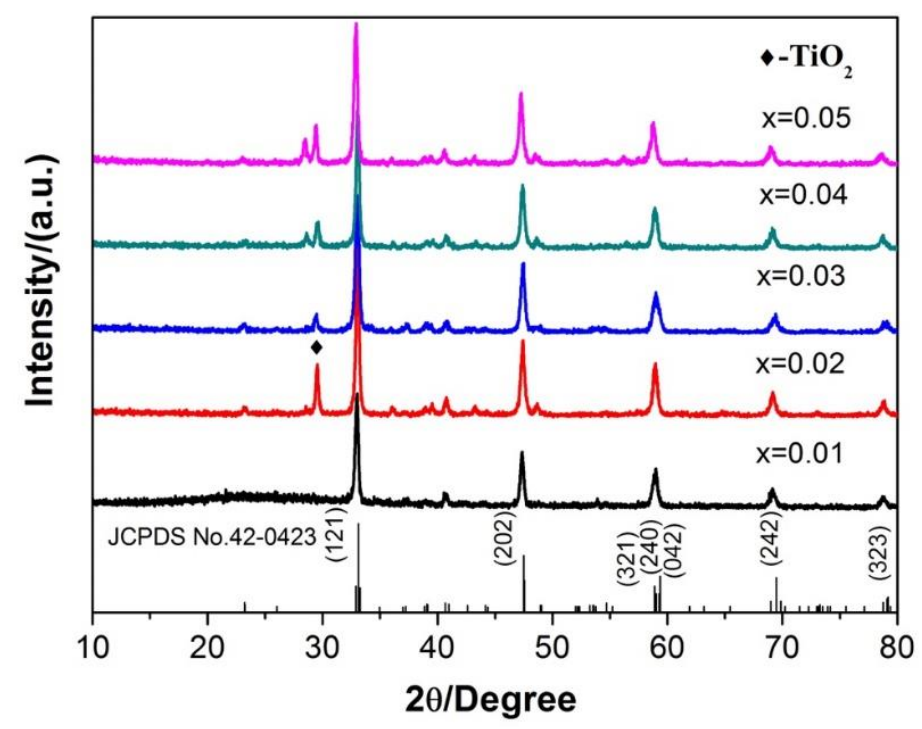

Figure 6. XRD patterns of the $\mathrm{Ca}_{1-\mathrm{x}} \mathrm{TiO}_{3}: \mathrm{Eu}^{3+}$ x phosphors doped with various concentrations of $\mathrm{Eu}^{3+}$ synthesized by the traditional sintering processes.

Figure 7 shows the emission spectra under an excitation wavelength of $398 \mathrm{~nm}$ of $\mathrm{Ca}_{1-\mathrm{x}} \mathrm{TiO}_{3}: \mathrm{Eu}^{3+}{ }_{\mathrm{x}}$ phosphors doped with various concentrations of $\mathrm{Eu}^{3+}$. The emission spectrum mainly presents four emission peaks, located at $597 \mathrm{~nm}, 617 \mathrm{~nm}, 658 \mathrm{~nm}$, and $700 \mathrm{~nm}$, respectively, under excitation wavelength of $398 \mathrm{~nm}$, which correspond to excited state ${ }^{5} \mathrm{D}_{0} \rightarrow{ }^{7} \mathrm{~F}_{\mathrm{J}}(\mathrm{J}=1 \sim 4)$ transition of the $\mathrm{Eu}^{3+}$ ion. The main emission peak is at $617 \mathrm{~nm}\left({ }^{5} \mathrm{D}_{0} \rightarrow{ }^{7} \mathrm{~F}_{2}\right)$, which corresponds to the red light band. The ${ }^{5} \mathrm{D}_{0} \rightarrow{ }^{7} \mathrm{~F}_{2}$ transition is the electric dipole transition. When the $\mathrm{Eu}^{3+}$ ion occupies the asymmetric position, the electric dipole transition will be the main transition, which also proves the replacement of $\mathrm{Eu}^{3+}$ ions in the crystal structure to $\mathrm{Ca}^{2+}$ ions.

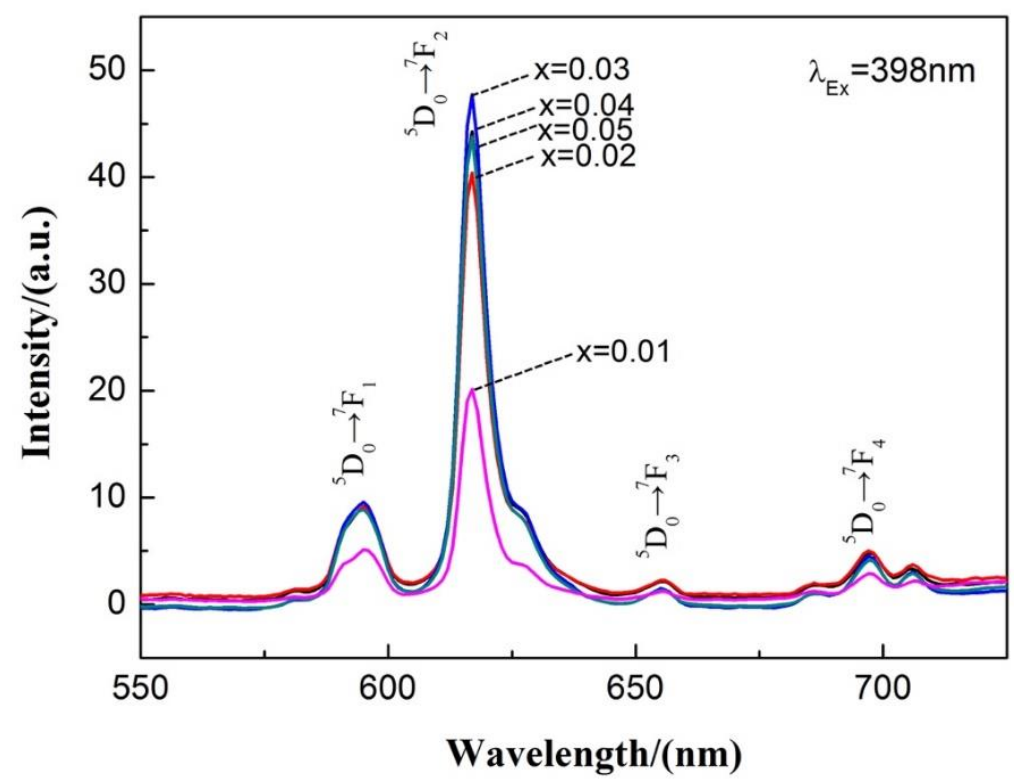

Figure 7. Emission spectra under an excitation wavelength of $398 \mathrm{~nm}$ of the $\mathrm{Ca}_{1-\mathrm{x}} \mathrm{TiO}_{3}: \mathrm{Eu}^{3+}{ }_{\mathrm{x}}$ phosphors doped with various concentrations of $\mathrm{Eu}^{3+}$ synthesized by the traditional sintering processes.

With the addition of $\mathrm{Eu}^{3+}$ ion doping amount, more luminescent centers are formed in the matrix, which increases the luminescence intensity. The emission intensity appears to reduce after it reaches the maximum at $x=0.03(3 \mathrm{~mol} \%)$. This is due to the interaction between the luminescent centers 
by increasing the $\mathrm{Eu}^{3+}$ concentration, the continuous migration of the excitation energy between the centers will not generate effective radiation. Therefore, $3 \mathrm{~mol} \%$ is the best doping concentration of $\mathrm{Eu}^{3+}$.

Table 1. Lattice parameters of $\mathrm{Ca}_{1-\mathrm{x}} \mathrm{TiO}_{3}: \mathrm{Eu}^{3+}$ x phosphors doped with various concentrations of $\mathrm{Eu}^{3+}$.

\begin{tabular}{cccccc}
\hline \multirow{2}{*}{ Phosphor } & \multicolumn{5}{c}{ Lattice Parameters } \\
\cline { 2 - 6 } & $\mathbf{X}$ & $\mathbf{a}(\AA)$ & $\mathbf{b}(\AA)$ & $\mathbf{c}(\AA)$ & $\mathbf{v}\left(\AA^{3}\right)$ \\
\hline & 0.01 & 5.442 & 7.649 & 5.421 & 225.654 \\
& 0.02 & 5.440 & 7.665 & 5.404 & 225.334 \\
$\mathrm{Ca}_{1-\mathrm{x}} \mathrm{TiO}_{3}: \mathrm{Eu}^{3+} \mathrm{x}$ & 0.03 & 5.439 & 7.645 & 5.403 & 224.927 \\
& 0.04 & 5.419 & 7.662 & 5.406 & 224.460 \\
& 0.05 & 5.433 & 7.662 & 5.377 & 223.832 \\
\hline
\end{tabular}

\section{3. $\mathrm{Ca}_{0.97} \mathrm{TiO}_{3}: \mathrm{Eu}^{3+}{ }_{0.03}$ Phosphor Synthesized by the Microwave-Assisted Sintering}

Microwave-assisted sintering has many advantages, including rapid heating and energy saving. However, the $\mathrm{Ca}_{0.97} \mathrm{TiO}_{3}: \mathrm{Eu}^{3+}{ }_{0.03}$ phosphor cannot absorb the microwaves; thus, a small crucible with dry $\mathrm{Ca}_{0.97} \mathrm{TiO}_{3}: \mathrm{Eu}^{3+}{ }_{0.03}$ phosphor powder was placed in a large crucible filled with $3 / 4$ volume of activated carbon. The activated carbon was heated using $2.45 \mathrm{GHz}$ microwave radiation with a maximum power of $800 \mathrm{~W}$. The precursor was heated by heat transfer from the activated carbon to prepare the $\mathrm{Ca}_{0.97} \mathrm{TiO}_{3}: \mathrm{Eu}^{3+}{ }_{0.03}$ phosphor. We note that the sintering atmosphere in the microwave oven might also slightly change due to the existence of activated carbon underneath the sample crucible. To record the temperature in the microwave oven, we placed a thermocouple into the crucible. The insulation inside the microwave oven is relatively poor, thus, we used an electric potential difference meter to calibrate the instantaneous temperature.

Figure 8 shows the XRD patterns of the $\mathrm{Ca}_{0.97} \mathrm{TiO}_{3}: \mathrm{Eu}^{3+}{ }_{0.03}$ phosphor samples sintered at different power. It can be seen in Figure $8 \mathrm{a}$ that the $\mathrm{Ca}_{0.97} \mathrm{TiO}_{3}: \mathrm{Eu}^{3+}{ }_{0.03}$ phosphor can be synthesized with microwave-assisted heating at $800 \mathrm{~W}$ for $30 \mathrm{~min}$ (at a temperature around $1100{ }^{\circ} \mathrm{C}$ ) while still in the presence of $\mathrm{TiO}_{2}$ crystals, which indicates $30 \mathrm{~min}$ is not long enough for the fully crystallization of the $\mathrm{Ca}_{0.97} \mathrm{TiO}_{3}: \mathrm{Eu}^{3+}{ }_{0.03}$ phosphor prepared by microwave-assisted sintering at $800 \mathrm{~W}$. The diffraction peaks of the samples are corresponding to the standard cards JCPDS NO.42-0423, which is, the orthorhombic $\mathrm{CaTiO}_{3}$ structure. From Figure 8b, we can see that the $\mathrm{Ca}_{0.97} \mathrm{TiO}_{3}: \mathrm{Eu}^{3+}{ }_{0.03}$ phosphor is fully crystallized at the power of $680 \mathrm{~W}$ for $50 \mathrm{~min}$ (at a temperature around $1025^{\circ} \mathrm{C}$ ). The results in Figure $8 \mathrm{c}$ is in agreement with Figure $8 b$, where the pure $\mathrm{Ca}_{0.97} \mathrm{TiO}_{3}: \mathrm{Eu}^{3+}{ }_{0.03}$ phosphor were synthesized at $528 \mathrm{~W}$ for $50 \mathrm{~min}$ (at a temperature around $950^{\circ} \mathrm{C}$ ). Therefore, a sintering duration of 50 min can synthesize the pure $\mathrm{Ca}_{0.97} \mathrm{TiO}_{3}: \mathrm{Eu}^{3+}{ }_{0.03}$ phosphor in a microwave oven at different power, where, a power of $528 \mathrm{~W}$ for $50 \mathrm{~min}$ is the most energy-efficient way.

(a)

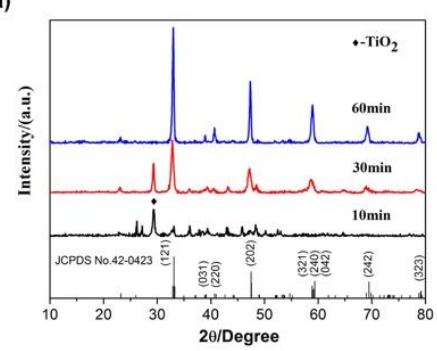

(b)

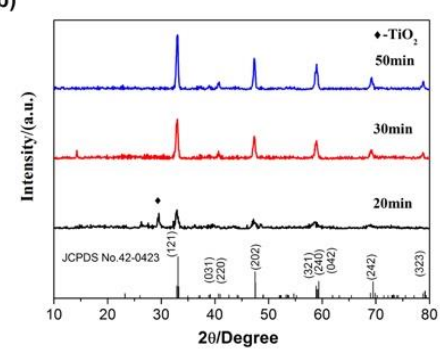

(c)

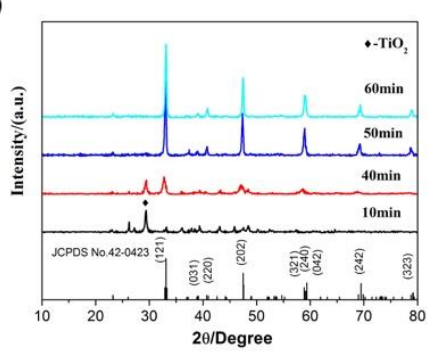

Figure 8. XRD patterns of the $\mathrm{Ca}_{0.97} \mathrm{TiO}_{3}: \mathrm{Eu}^{3+}{ }_{0.03}$ sintered at different microwave sintering power. (a) $800 \mathrm{~W}$; (b) $680 \mathrm{~W}$; (c) $528 \mathrm{~W}$.

Figure 9 shows the emission spectra under an excitation wavelength of $398 \mathrm{~nm}$ of $\mathrm{Ca}_{0.97} \mathrm{TiO}_{3}: \mathrm{Eu}^{3+}{ }_{0.03}$ prepared at different microwave sintering power $(800 \mathrm{~W}, 680 \mathrm{~W}$, and $528 \mathrm{~W})$. It can be seen from Figure 9 that, under an excitation wavelength of $398 \mathrm{~nm}$, the emission spectrum 
mainly includes four emission peaks $(597 \mathrm{~nm}, 617 \mathrm{~nm}, 658 \mathrm{~nm}, 700 \mathrm{~nm})$, which correspond to the ${ }^{5} \mathrm{D}_{0} \rightarrow{ }^{7} \mathrm{~F}_{\mathrm{J}}(\mathrm{J}=1 \sim 4)$ transition of $\mathrm{Eu}^{3+}$ ion. Moreover, with the sintering time prolonged, the emission intensity firstly increased to a peak at $50 \mathrm{~min}$ and then decreased. A sintering time of $60 \mathrm{~min}$ will not significantly increase the emission intensity, which is due to the completion of the crystallization process.
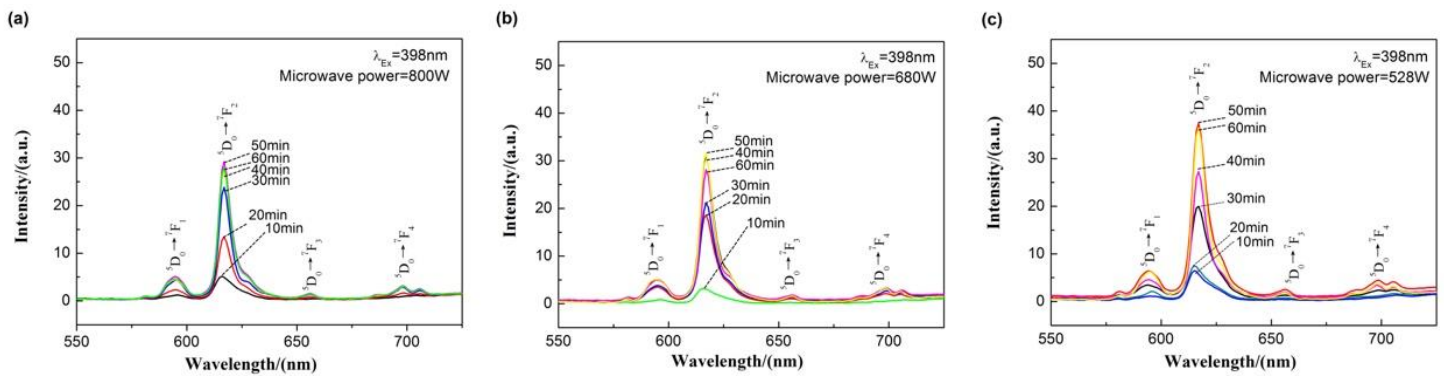

Figure 9. Emission spectra under an excitation wavelength of $398 \mathrm{~nm}$ of the $\mathrm{Ca}_{0.97} \mathrm{TiO}_{3}: \mathrm{Eu}^{3+}{ }_{0.03}$ prepared at different microwave sintering power. (a) $800 \mathrm{~W}$; (b) $680 \mathrm{~W}$; (c) $528 \mathrm{~W}$.

Figure 10 shows the emission spectra under an excitation wavelength of $398 \mathrm{~nm}$ of $\mathrm{Ca}_{0.97} \mathrm{TiO}_{3}: \mathrm{Eu}^{3+}{ }_{0.03}$ synthesized by microwave-assisted methods and traditional furnace sintering method. A sintering power of $528 \mathrm{~W}$ for $50 \mathrm{~min}$ by microwave oven gets the similar emission intensity results as the traditional furnace sintering at $900{ }^{\circ} \mathrm{C}$ for $2.5 \mathrm{~h}$. The emission intensity will significantly decrease when we further increase the power. Indeed, the microwave-assisted sintering will greatly save the energy and time for the preparation of $\mathrm{Ca}_{0.97} \mathrm{TiO}_{3}: \mathrm{Eu}^{3+}{ }_{0.03}$ red phosphor with good luminescent performance.

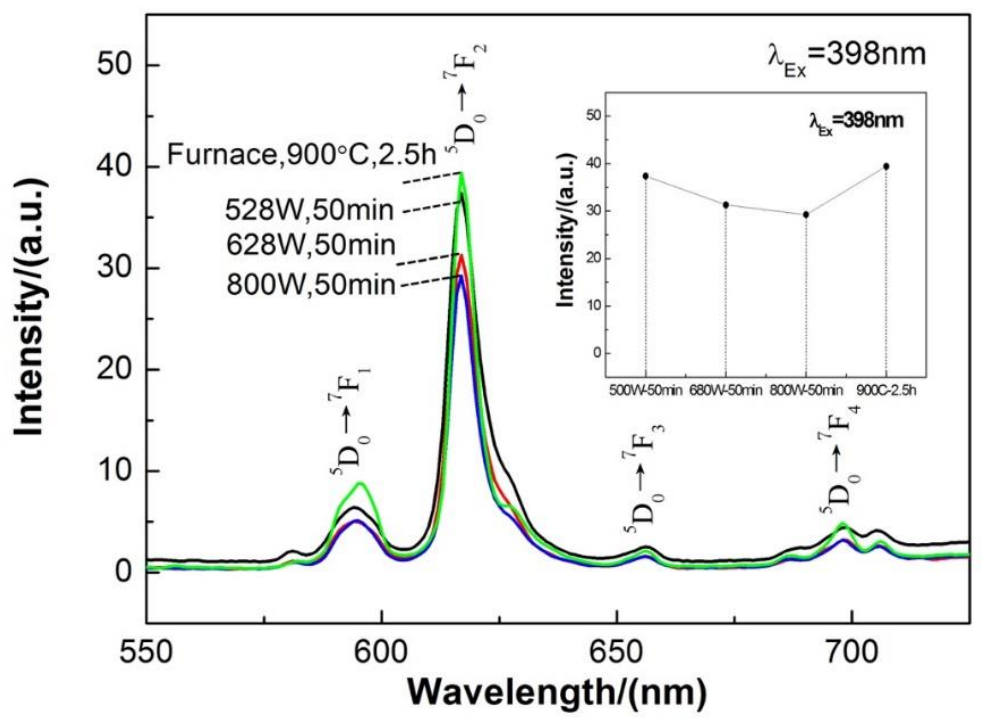

Figure 10. Emission spectra under an excitation wavelength of $398 \mathrm{~nm}$ of the $\mathrm{Ca}_{0.97} \mathrm{TiO}_{3}: \mathrm{Eu}^{3+}{ }_{0.03}$ synthesized by the traditional sintering process (furnace) and microwave-assisted sintering process.

Figure 11 shows the morphology of $\mathrm{Ca}_{0.97} \mathrm{TiO}_{3}: \mathrm{Eu}^{3+}{ }_{0.03}$ phosphors (best doping) synthesized by the different synthesize methods and scanned by SEM. It can be seen from Figure 11a,b that both of the $\mathrm{CaTiO}_{3}: \mathrm{Eu}^{3+}{ }_{0.03}$ phosphors have a rod shape, which agrees with the orthorhombic perovskite structure from the XRD results. However, the $\mathrm{CaTiO}_{3}: \mathrm{Eu}^{3+}{ }_{0.03}$ phosphors synthesized by the microwave-assisted sintering process are slightly bigger while containing numerous defects on the surface compared to the ones prepared by the traditional sintering processes. The imperfection of the shape of the $\mathrm{CaTiO}_{3}: \mathrm{Eu}^{3+}{ }_{0.03}$ phosphors is attributed to the rapid and shorter sintering process in a microwave oven. 

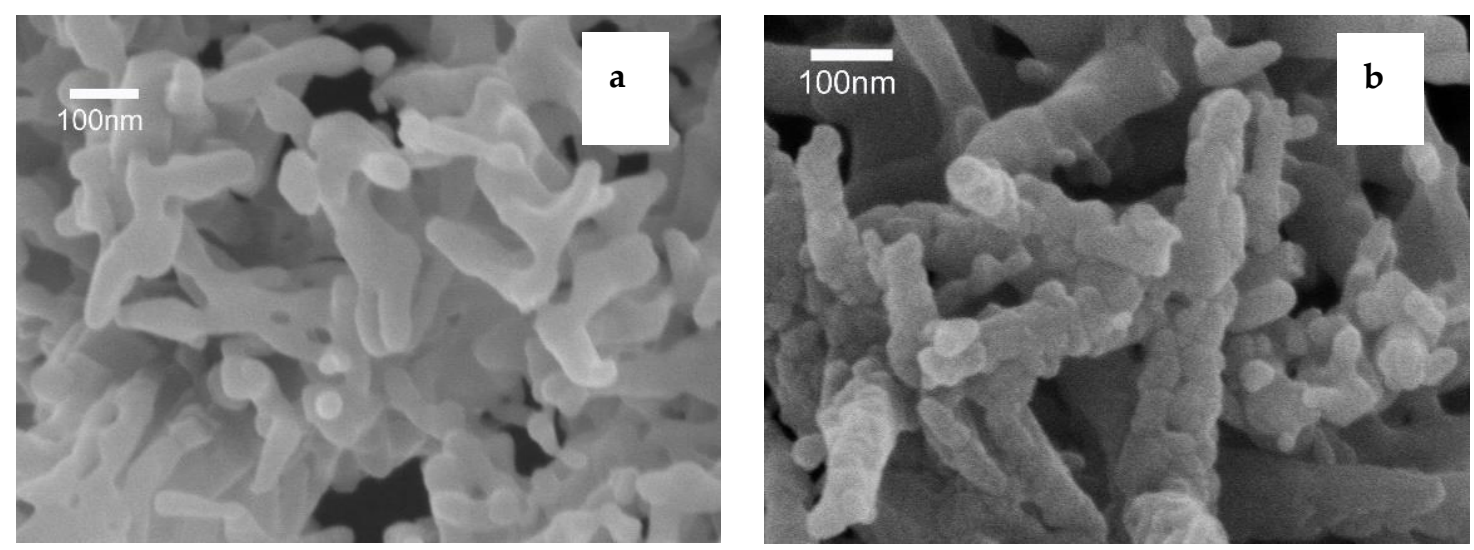

Figure 11. Morphology of $\mathrm{Ca}_{0.97} \mathrm{TiO}_{3}: \mathrm{Eu}^{3+}{ }_{0.03}$ phosphors: (a) synthesized by the traditional sintering processes; (b) synthesized by the microwave-assisted sintering process.

\section{Conclusions}

In this work, the feasibility of synthesizing $\mathrm{Ca}_{1-\mathrm{x}} \mathrm{TiO}_{3}: \mathrm{Eu}^{3+}{ }_{x}$ phosphor with a good luminescent performance by combining the chemical co-precipitation method and microwave-assisted sintering was studied. First, the precursor was synthesized by the chemical co-precipitation method, which was confirmed by the FT-IR test. Then, we synthesized the $\mathrm{Ca}_{1-\mathrm{x}} \mathrm{TiO}_{3}: \mathrm{Eu}^{3+}$ phosphor by traditional (furnace) sintering based on the TG-DSC analysis of the precursors. We found that the $\mathrm{Ca}_{1-\mathrm{x}} \mathrm{TiO}_{3}: \mathrm{Eu}^{3+} \mathrm{x}$ phosphor reached a peak emission intensity with a doping amount of $3 \mathrm{~mol} \% \mathrm{Eu}^{3+}$ and traditional sintering temperature of $900^{\circ} \mathrm{C}$ for $2.5 \mathrm{~h}$. Finally, we applied the microwave-assisted sintering with powers from $528 \mathrm{~W}$ to $800 \mathrm{~W}$ (temperature from $950-1100{ }^{\circ} \mathrm{C}$ ) to prepare the $\mathrm{Ca}_{0.97} \mathrm{TiO}_{3}: \mathrm{Eu}^{3+}{ }_{0.03}$ phosphor and found that a sintering power of $528 \mathrm{~W}$ for 50 mins by microwave oven resulted in similar emission intensity results compared to traditional furnace sintering at $900{ }^{\circ} \mathrm{C}$ for $2.5 \mathrm{~h}$. The new synthesized method will greatly save energy and time and is an environmentally friendly method for the preparation of $\mathrm{Ca}_{0.97} \mathrm{TiO}_{3}: \mathrm{Eu}^{3+}{ }_{0.03}$ red phosphor with good luminescent performance.

Author Contributions: Methodology, H.W.; formal analysis, H.W., J.L., R.W., Y.D. and L.D.; data curation, H.W., J.L., R.W. and Y.D.; writing-original draft preparation, H.W. and L.D.; writing-review and editing, H.W. and L.D.; supervision, H.W.; funding acquisition, H.W. All authors have read and agreed to the published version of the manuscript.

Funding: This study was supported by the National Key Research and Development Program of China (Grant No. 2017YFB0309003) and the Initial Research Funds for Young Teachers of Donghua University (Grant No. 106-07-0053039).

Conflicts of Interest: The authors declare that they have no conflict of interest.

\section{References}

1. Orihashi, T.; Adachi, S. Synthesis condition and structural/luminescent properties of $\mathrm{CaTiO}_{3}: \mathrm{Eu}^{3+} \mathrm{red}$ phosphor. J. Alloy. Compd. 2015, 646, 1116. [CrossRef]

2. Mazzo, T.M.; Moreira, M.L.; Pinatti, I.M.; Picon, F.C.; Leite, E.R.; Rosa IL, V.; Varela, J.A.; Perazolli, L.A.; Longo, E. $\mathrm{CaTiO}_{3}: \mathrm{Eu}^{3+}$ obtained by microwave assisted hydrothermal method: A photoluminescent approach. Opt. Mater. 2010, 32, 990. [CrossRef]

3. Liu, P.; Yin, J.; Mi, X.; Zhang, L.; Bie, L. Enhanced photoluminescence of $\mathrm{CaTiO}_{3}: \mathrm{Eu}^{3+}$ red phosphors prepared by $\mathrm{H}_{3} \mathrm{BO}_{3}$ assisted solid state synthesis. J. Rare Earths 2013, 31, 555. [CrossRef]

4. Oliveira, L.H.; Savioli, J.; de Moura, A.P.; Nogueira, I.C.; Li, M.S.; Longo, E.; Varela, J.A.; Rosa, I.L.V. Investigation of structural and optical properties of $\mathrm{CaTiO}_{3}$ powders doped with $\mathrm{Mg}^{2+}$ and $\mathrm{Eu}^{3+}$ ions. J. Alloy. Compd. 2015, 647, 265. [CrossRef]

5. Ha, M.G.; Lee, J.H.; Bae, J.S.; Kim, J.P.; Hong, K.S.; Yang, H.-S. Photophysical properties of highly efficient red-emitting $\mathrm{CaTiO}_{3}: \mathrm{Eu}^{3+}$ phosphors under near ultra-violet excitation. Curr. Appl. Phys. 2011, 11, 1379. [CrossRef] 
6. Som, S.; Kunti, A.K.; Kumar, V.; Kumar, V.; Dutta, S.; Chowdhury, M.; Sharma, S.K.; Terblans, J.J.; Swart, H.C. Defect correlated fluorescent quenching and electron phonon coupling in the spectral transition of $\mathrm{Eu}^{3+}$ in $\mathrm{CaTiO}_{3}$ for red emission in display application. J. Appl. Phys. 2014, 115. [CrossRef]

7. Yang, W.; $\mathrm{Hu}, \mathrm{J}$. Synthesis and luminescence properties of hexagonal $\mathrm{CaTiO}_{3}: \mathrm{Eu}^{3+}$ nanosheets. J. Lumin. 2014, 145, 144. [CrossRef]

8. Wu, Y.-F.; Nien, Y.-T.; Wang, Y.-J.; Chen, I.-G.; McKittrick, J. Enhancement of Photoluminescence and Color Purity of $\mathrm{CaTiO}_{3}: E u$ Phosphor by Li Doping. J. Am. Ceram. Soc. 2012, 95, 1360. [CrossRef]

9. Singh, D.K.; Manam, J. Structural and luminescence properties of $\mathrm{CaTiO}_{3}: \mathrm{Eu}^{3+}$ phosphor synthesized by chemical co-precipitation method for the application of solid state lighting devices. Aip Conf. Proc. 2016, 1728. [CrossRef]

10. Đačanin, L.R.; Lukić-Petrović, S.R.; Petrović, D.M.; Nikolić, M.G.; Dramićanin, M.D. Temperature quenching of luminescence emission in $\mathrm{Eu}^{3+}$ - and $\mathrm{Sm}^{3+}$ - doped $\mathrm{YNbO}_{4}$ powders. J. Lumin. 2014, 151, 82.

11. Zhang, P.; Xu, M.-X.; Zheng, Z.-T.; Sun, B.; Zhang, Y.-H. Microwave synthesis and characterization of new red long afterglow phosphor $\mathrm{Sr}_{3} \mathrm{Al}_{2} \mathrm{O}_{6}$ : Eu. Trans. Nonferrous Met. Soc. China 2006, 16, S423-S425. [CrossRef]

12. Chen, H.-Y.; Weng, M.-H.; Chang, S.-J.; Yang, R.-Y. Preparation of $\mathrm{Sr}_{2} \mathrm{SiO}_{4}$ : $\mathrm{Eu}^{3+}$ phosphors by microwave-assisted sintering and their luminescent properties. Ceram. Int. 2012, 38, 125. [CrossRef]

13. Cai, W.; Fu, C.; Hu, W.; Chen, G.; Deng, X. Effects of microwave sintering power on microstructure, dielectric, ferroelectric and magnetic properties of bismuth ferrite ceramics. J. Alloy. Compd. 2013, 554, 64. [CrossRef]

14. Wang, Y.-F.; Liu, L.; Xie, R.-J.; Huang, Q. Microwave assisted sintering of thermally stable $\mathrm{BaMgAl}_{10} \mathrm{O}_{17}$ : $\mathrm{Eu}^{2+}$ phosphors. Ecs J. Solid State Sci. Technol. 2013, 2, 196. [CrossRef]

15. Rybakov, K.I.; Olevsky, E.A.; Krikun, E.V. Microwave sintering: Fundamentals and modeling. J. Am. Ceram. Soc. 2013, 96, 1003. [CrossRef]

16. Potdar, H.; Deshpande, S.; Deshpande, A.; Khollam, Y.; Patil, A.; Pradhan, S.; Date, S. Simplified chemical route for the synthesis of barium titanyl oxalate (BTO). Int. J. Inorg. Mater. 2001, 3, 613. [CrossRef]

17. Malghe, Y.; Gurjar, A.; Dharwadkar, S. Synthesis of $\mathrm{BaTiO}_{3}$ powder from barium titanyl oxalate (BTO) precursor employing microwave heating technique. Bull. Mater. Sci. 2004, 27, 217. [CrossRef]

18. Feng, H.; Li, X.; Ji, H.; Zhou, Z. Preparation of $\mathrm{Ba}_{0.55} \mathrm{Sr}_{0.4} \mathrm{Ca}_{0.05} \mathrm{TiO}_{3}$ Powders by Chemical Co-Precipitation for Low Temperature Sintering Ferroelectric Ceramics. Integr. Ferroelectr. 2011, 129, 95. [CrossRef]

19. Cheng, Y.; Liu, X.; Guo, J.; Liu, F.; Li, Z.; Xu, G.; Cui, P. Fabrication of uniform core-shell structural calcium and titanium precipitation particles and enhanced electrorheological activities. Nanotechnology 2009, 20. [CrossRef]

20. Lee, H.-G.; Gopalan, A.-I.; Sai-Anand, G.; Lee, B.-C.; Kang, S.-W.; Lee, K.-P. Facile synthesis of functionalized graphene-palladium nanoparticle incorporated multicomponent $\mathrm{TiO}_{2}$ composite nanofibers. Mater. Chem. Phys. 2015, 154, 125-136. [CrossRef]

21. Hezam, M.; Qaid SM, H.; Bedja, I.M.; Alharbi, F.; Nazeeruddin, M.K.; Aldwayyan, A. Synthesis of Pure Brookite Nanorods in a Nonaqueous Growth Environment. Crystals 2019, 9, 562. [CrossRef]

(C) 2020 by the authors. Licensee MDPI, Basel, Switzerland. This article is an open access article distributed under the terms and conditions of the Creative Commons Attribution (CC BY) license (http://creativecommons.org/licenses/by/4.0/). 